\title{
Autonomy of human mind and personality development
}

\begin{abstract}
A psychology of human individual development is proposed which argues against its reduction to the description and control of human behavior or to cognitive psychology in the model of information and communication technology. Instead the author's earlier conceptualization of the autonomy of human individual development is now elaborated further. The foundational premise to this end rests in Macnamara's (1999) explication of Brentano's (1874) notion of intentionality, i.e., referring to something as an object. It reveals the access of the mind to the ideal objects and to the kinds which provide for identity and individuation of the objects of human cognition (Macnamara and Reyes, 1994). It converges with the anti-irrationalism postulate which was put forward by Ajdukiewicz (1934). The reduction of the mind in psychology to something else proves unable to meet the anti-irrationalism postulate, regards perception and cognition to be of one piece, and it excludes intuition and ideals. In contrast to this, the notions of the spontaneous and self-sustainable perception and the self-determined mind open a way for psychology without the reduction of it to anything else. The same route has been taken earlier (Niemczyński, 2007) with a study of personality development from adolescence to the late ages.
\end{abstract}

Key words: autonomy, development, mind, intentionality

Developmental psychology stems from evolutionary biology and treats human development within an individual life cycle as if it would be an ontogenetic development. Therefore, the development of an individual person is taken to be a maturation of their organism's adaptation abilities. The human mind is conceived to be an innate set of functions which the organism is designed to perform. Mind development is depicted to be progress toward possibly reaching an individual's full potential level, followed by regress after a period of maintaining it at the highest level reached.

To take the human mind to be a uniform or multiple adaptation function is an assumption which is rather dogmatically and widely accepted. It is so deeply entrenched that it passes without much questioning. With reference to the higher mental functions, however, the assumption seems to lose strength and sets no obstacle for loose speculations regarding how contemporary biological knowledge relates to the psychological conceptualizations of: thinking, creativity, free will, interpersonal sensitivities, sense of justice, responsibilities in social relations, etc. At the same time, no deep debate takes place which would refer to the question of how biology lays a foundation for the social nature of homo sapiens, for its cultural manner of life, or for the rise and development of human civilization in the history of humankind. Many different pieces of interesting information come from studies of higher mental functions, though they do not go beyond the scheme of biological adaptation to the environment.

One may argue that the way to study the human mind in relation to the biology of living organisms has been an enduring and difficult problem since the very emergence of psychology as an empirical science in XIX century soon after Darwin's publication of his theory of evolution (Niemczyński, 2015, 2016). It is worth noting that a reduction of the mind to something else is much older, going back to Hobbes (1651) who reduced it to Galileo's kinematics. The British empiricism of Locke (1690), Berkeley (1709), and Hume (1748) has been continued by John S. Mill (1843) to provide experimental psychology at its inception with the empiricists' theory of cognition. This is the manner in which psychology came to view operation on the data of senses as the only source of cognition.

Anti-reduction positions have been taken by two outstanding figures from the pioneering times of scientific psychology. Brentano (1874/1973) made a sharp distinction between psychology of the mind and physiological psychology, and Wundt (1897) went beyond psychophysical experiments to Voelkerpsychologie (1900-1920). Their attempts to develop a psychology of the mind

\footnotetext{
* Katowice School of Economics, Jagiellonian University

Corresponding author: upniemcz@cyf-kr.edu.pl
} 
without falling into the fallacies of reductionism still wait to be continued after decades of being abandoned by psychologists.

My earlier opposition to reductionism in psychological investigations has been developed without reference to either Brentano or Wundt. Rather, it used inspirations from the philosophical investigations of Husserl (1900, 1901), Ingarden (1948, 1972), Ajdukiewicz (1934, 1958) and Hempoliński (2005). It also drew upon the psychological work of Vygotsky (1971) on the development of higher mental functions and from humanistic ideas in psychiatry as proposed by Kępiński (1973), who argued for an integrated whole out of the three cognitive planes of knowledge of man (biological, psychological and sociological) (Niemczyński, 1977, 1980a, 1980b, 1980c, 1980d, 1988a, 1988b, 1992, 1993). Since the commencement of my child development studies, I learned from Szuman (1959) - and from subsequent elaboration of his approach by Przetacznikowa (1973) - about a necessity to discern four factors in the determination of human mind development in childhood and adolescence. I also learned about the unique contribution to mind development of upbringing and education as a human-specific source of the child's own activity development within the social and cultural world of human adult life. Next was my research on the social-moral cognitive development (Niemczyński et al., 1988c; Niemczyński and Maciejowska, 1989; Czyżowska and Niemczyński, 1994; Golec, Niemczyński, 1995a; Koclega, Niemczyński, Ryniak, and Ziółkowska, 1995b) along the lines of Piaget (1934) and Kohlberg (1980, 1984), which has lead me to reject their biologically founded approach to the human mind (Niemczyński, 1996, 2014). Instead, a conceptualization of an inner regulatory device (IRD) of the mind and personality development (MPD) was elaborated and supported with data from a series of longitudinal studies with the participation of adolescents and adults (Niemczyński, 2007) The IRD proposal used a notion of morally significant group identities as elaborated by Blum (1994) to grasp a network of social relations in the course of human life, and it was Macnamara's retrieval of ideals for the psychology of human cognition that was used to conceive of MPD changes with years in terms of growth in adequacy of interpretation of the ideal of living a human life in relationships (Niemczyński, 2000, 2007). In Tischner (1982), I then found a specific aspect of the human mind manifesting itself in thinking according to values, and Fowler's (1981) investigation into faith development was another important source of arguing for human autonomy. From Wundt and Brentano, I turned to Macnamara's (1982, $1986,1990,1999)$ work on the history of psychological thought and the ideals and on the role intuition plays in human cognition, especially on the development of the human mind in its logical and semantic aspects. With this new knowledge and its implications, I am going back to further elaborate on my earlier proposal regarding the theory of autonomy of human mind and personality development (Niemczyński, 1994).

\section{Human individual person development in relation to ontogeny of homo sapiens}

Individual human development has a status of autonomy in contrast to the causal process of biological ontogeny of the particular representatives of the species homo sapiens. The last has been shaped by evolutionary history, which is not the history of civilization. If one studies the development of an individual human in the model of biological ontogeny, the process of reaching the prenatal and postnatal stages through maturity becomes the object of the study. As any other species has a specific ontogeny, the same is true of human ontogenetic development. Every representative of the homo sapiens species undergoes the same cycle of developmental changes, beginning with the initial stages through the stage of maturity and to the final stage of decline in adaptation to the environmental conditions of living.

There are three principal conceptual models of mental (psychic) development considered to be ontogenetic development (Niemczyński, 1994, 2007, 2011; see also Learner, 1986). These models include the maturational innate determination model as represented by Erikson (2004), the learning from experience of the environment model as exemplified by Skinner (1978), and a formal dialectical model as in Piaget (1977), which points to dynamic interactions of both the nature and nurture stimulation factors for the autonomous transformations of mental adaptation structures. For our purposes, it suffices to mention only the above examples to mark the multiplicity of conceptualizations of these three types of conceptual models of mental development. None of them go beyond the limits of biological determination. There is a clear equation sign between the development of an individual human and the human ontogeny in theories and research based on any of the three models.

However, development of the individual human mind and personality is not reducible to the homo sapiens ontogenetic development. I took this stance from the commencement of my research (Niemczyński, 1977, 1980, 1988, 1994). It has been elaborated further Niemczyński, 2000, 2007, 2015, 2016) following Brentano $(1874 / 1973)$ and Macnamara $(1990,1999)$ with the notion of intention; that is, referring to something as an object that differentiates the human mind from anything else in the world. No physiological process or function of a living organism of any human person can be taken to be an act of a subject refererence to an object, or a part or parcel of it. At the same time, each human thought is someone's thought of something, each human fear is someone's fear of something, every mental image is someone's image of something, every recollection is someone's recollection of something, every desire is someone's desire of something, every belief is someone's belief that things are as they are, and so forth. The subject refers to something in all of these examples. The very relation of 'referring to something else as an object' with any of its variants - thought, fear, imagination, expectation, recollection, desire, belief, etc. - define the autonomic domain of mind and personality. 
Neither Szuman (1959) nor Gierowska (1973) - who introduced me into the field of developmental psychology needed to use the notion of autonomy of child development. Vygotsky (1971) - from whom I also took inspiration in my first attempt to describe the theory of human individual development (Niemczyński, 1977, 1980, 1988b) - felt no need to take autonomy into account in his study of the development of higher mental functions. The term itself has been applied in literature on adolescent development, but with a different meaning of an urge of liberation from adults' control. One may find in Szuman (1959), as well as in Gierowska (1973), the notion of child mental activity coming from needs, inclinations, and aspirations, and that they are developed as the results of upbringing and education. However, it is not yet clear how much the socially shaped activity of children and the socialcultural processes involved constitute an autonomous domain. In Szuman (2014), there is a theme of personality development and a reference to values in a classical triadic set of truth, good, and beauty; but it is not clear what it implies for the theory of human person development. Nonetheless, it preserves a significance of inspiration to further the theory and research in the field. There is no doubt, however, that in Szuman's investigations and in her student Przetacznikowa's work, as well as in the studies by the next generation of Kraków School of Developmental Psychology, the present author included, one may find a clear and coherent dualistic approach encompassing both the basic biological conditions and the social-cultural determination of child development.

As was briefly mentioned, Piaget (1926, 1936, 1955, 1975) considered the child's own active adaptation to be the intelligence which undergoes the autonomous series of structural transformations with age. He liberated the structure (or any and all stages) of mental functioning of the child from any morphological-physiological and any environmental-educational determinations. Both are necessary for mental development, but they can only speed up or slow down the autonomous mental development which has its own exclusive determination. Mental functioning and its transformations govern themselves according to the principles of reaching equilibrium between cognitive assimilation of information from the environment and accommodation of the cognitive structure to fit to what is received from the environment. The adaptive developmental changes of the actual cognitive structure begin with assimilation of novelty which is optimal: not too small to be ignored and not too big to pass unnoticed. Each time optimal novelty stimulates the actual adaptation activity structure by being partly assimilated and provides for its disequilibrium, a new accommodation cycle is started, which builds a new cognitive structure. This secures the assimilation of both the old and the new environmental stimulations to the new emerging cognitive structure. In this manner, cognition develops itself, reaching the consecutive equilibrium states up to the final state, in which any environmental challenge for mental adaptation may be accommodated without building a new activity structure. For this reason, human intelligence is considered cognitive adaptation to the environment when it reaches its final stage of perfect equilibration dynamics in the mental organization of formal logical operations.

The notion of autonomy in Piaget's theory does not have any commonality with the notion of autonomy of the individual human mind and personality development, which is further explained here. Piaget reduces mind and personality to biological adaptation. As a consequence, the subject is reduced to the process of the living organism and the object is reduced to the environment of the living organism. The relationship between them is reduced to the relationship of an organism to its environment - that is, to the biological adaptation. In contrast, the autonomy of an individual person development implies the irreducibility of mind and personality to anything else. The subject, the object, and the relationship between the two are reducible neither to each other nor to anything else.

For example, my hope for the recovery of my close relative is not reducible to the state of my organism, despite the fact that I would not have this hope if my organism was not in sufficiently good condition. It is certainly a fact that my hope may influence my organism's state in a different way than, let us say, my despair from the same reason. My hope is a triad of (1) my act in which me, and nobody else (2) refers to (3) the objective state of the recovering of my close relative and not of any other person, and (2a) I refer to hoping for recovery, and neither with $(2 b)$ predicting it on medical evidence, nor with (2n) one of many other kinds of modus operandi I can decide to use in this case.

It is worth notice that it may remind us of Allport's $(1937,1963)$ functional autonomy when we consider states of mind which are not reducible to the physiological states of an organism, such as to hope for something, to grieve for someone, or to have confidence in someone. However, this is not the case with Allport, who, in his final stage of the analysis, did reduce the functional autonomy to a pattern of brain activity. He discerned two versions of functional autonomy: preservative functional autonomy and propriety functional autonomy. The first may be easily observed as soon as childhood, while the second plays a crucial role in the formation of personality traits in adolescence. Both originate as a departure from the innate biological purpose to either simply repeat themselves out of the original motivational context (preservative functional autonomy) or by becoming a value in themsevles as the general feature of functioning in the social-cultural world (propriety functional autonomy). For instance, when an action satisfying a primary drive is performed within some contexts in a graceful and elegant manner, it is the value of acting with grace and elegance that becomes an autonomous motive proper to acting in all social-cultural contexts.

Allport argued that the autonomous realm of culturally recognized manners of social activity may be found in natural language expressions and to this end, he provided a list of 17,953 items from the English language vocabulary of his time (Allport \& Odbert, 1936). As a result of several sorting steps of lexical resources, a few sets of general traits of personality have emerged. They are shaped in childhood 
and adolescence and they express themselves with different intensity levels and different levels of integration into the whole of particular compositions of traits. They may form the unique personality characterizations, also including fewer general traits and even exceptional and unrepeatable ones.

The personality traits enrooted in the biology of an organism and the unequivocal conviction by Allport (1931) that in the future the brain processes of personality regulations will be discovered reveal that Allport's functional autonomy of personality traits remains to be a feature of human ontogenetic development. In a similar manner, the contemporary field of studies of the individual differences of personality, intelligence, and temperament is immersed in the allusions to brain and its physiology as a consequence of the conceptualizations of their significance of the adaptation to environment.

Although I attempted to argue for irreducibility of mental to biological by pointing to the radical difference between the principles according to which the events and processes take place in the two domains (and it was summarized in Niemczyński (1994)), it was only later that it has been supported by the appeal to the intentional (referential) relationship of a subject to the object (Niemczyński, 2000, 2007). The very intentional relationship demands our attention if we must continue.

Brentano (1874/1973) made an appeal to the intentional (referential) relationship to differentiate psychology of mind from physiological psychology. Macnamara (1999) noticed that Brentano did not succeed in providing a satisfactory explication of it. Repeatedly returning to the task, he continued to reject the numerous solutions that arose and left without a satisfactory solution. Accepting Bretano's indications, Macnamara provided us with his own elaboration of the 'reference to something else as an object'. Macnamara's elaboration lays foundations to psychology of mind and discerns it sharply and completely from the physiological psychology.

Macnamara (1999) begins with finding that the unequivocal dualism in Brentano (1874/1973) has an epistemological significance. It is related to a distinction that Brentano made between introspection, considered inner observation, and inner perception. He rejected the first, arguing that it is illusory and accepted the second to be authentic and a principal source of basic empirical data for psychology of mind. Brentano (1973) wrote: "If someone ... wants to observe his own anger raging within him, the anger must already be somewhat diminished, and so his original object of observation would have disappeared. ... It is a universally valid psychological law that we can never focus our attention upon the object of inner perception. It is only while our attention is turned toward a different object that we are able to perceive, incidentally, the mental processes that are directed towards that object." Macnamara (1999) sums up: "Mental phenomena themselves, rather than what the phenomena are about, can never be the direct object of attention" and continues with a comment on Brentato's point: "If you see a cow, for example, the cow is the object of your vision, and you may attend to her as much as you wish. You are also aware, incidentally, that you are seeing her, not imagining or touching her. You are further aware, incidentally, that it is you, not your friend, who is having this experience of seeing. The cow is the object of the outer perception; the facts that you are seeing, not touching, and that it is you who is having the experience are given incidentally in inner perception."

Macnamara remarks that inner perception is, in fact, intuition providing immediate insight into the properties of an object and he notes that intuition can be verified and corrected. There is no reason in critical mood in which intuitive certainty would not be open to corrections by other intuitions. Exactly the same happens when evidence of the senses and experimental data, as well as the outcomes of scientific observations are amenable to tests and corrections by pieces of evidence of the same kind. The postulates of being socially communicable and correctable are maintained with reference to the data of intuition as much the same as to scientific empirical data although it demands considerable training and effort to be able to properly use the intuition capabilities. It reminds the linguistic intuition that Chomsky $(1957,1959)$ invoked to study the syntactic structures of natural languages. Macnamara (1984, 1986) applied it to investigate the logical and semantic aspects of the referential acts of the human mind.

We now have one of the ways Macnamara presents his discovery of the nature of mental acts. By repeatedly perceiving and observing his pet dog, Freddy, Macnamara says "Freddy is a dog" and argues that it is not possible to grasp the meaning of this sentence without access to the proper kind in order to identify and individuate Freddy. The kind here is DOG. It is written in upper case letters to discern from particular dogs. It is not possible to perceive particular dogs or to identify any of them by proper name without reference to the kind, which is an abstract object and is accessible to intuition but not to the senses. Such is the logic of the mental act expressed in the sentence: "Freddy is a dog." Namely, there is a reference to the abstract object, the kind DOG to individuate any one particular dog who lives now, who lived in the past, and who will live in the future. Each of the references by the subject to the object performs object identification with a proper kind and object individuation as one of the kind. Such is the essence of the intentional (referential) nature of the mental acts; that there is "... no reference without support of a kind to provide for individuation and identity of what is referred to" (Macnamara, 1999).

Reference to Freddy cannot be reduced to physiology for the same reasons why a physiologist has no logical resources to explain how neural states or processes can come into contact with an abstract object. One should notice that the physical objects that cause visual perceptions of Freddy are parts of the surface of his body. However, these surfaces are not Freddy, who remains to be Freddy, even after all his fur is shaved and all of the cells of the surface are removed. The role played by the kinds like DOG are fundamental in cognition, which is why any attempt to reduce what is mental to what is physiological should be rejected as a distortion of reality. 
The kinds supply necessary support for identification and individuation of the particular objects of both perception and propositions (Macnamara, 1986). I shall come back to this issue later. The most urgent question is regarding what the mutual relationship is between what is biological and what is mental and personal once the identity theory is rejected and a dualism enters.

\section{Mind and personality development versus changes of behavior with age}

It was suggested in my previous attempt of pointing to the human mind and personality development autonomy that it refers to "... a process which takes place (a) by stretching throughout the individual life cycle; (b) and producing its own normative model; (c) to play the role of its own course inner regulatory device; (d) which is flexible and set gradually the individual person development within the human life cycle to a close down in the production of the contributions to the social-cultural world" (Niemczyński, 1994). It may be noticed that no reference to the behavior of organisms has been used to point to the object of knowledge to be gained by developmental psychology studies. It implies not only the rejection of behavioral psychology, but also the dismissal of all remains left by behaviorism. Much of what behaviorism has left is more than is usually admitted.

Watson's (1913) appearance in America became a revolutionary change, which engulfs psychology everywhere and has been the dominating paradigm throughout the field of psychology for about a half century, not recessing completely until present. It is worth recollecting the reasons that revolutionized the scholarship of psychology in this manner and what the essence of behaviorism is.

Watson's proposal became so immensely attractive in America mainly due to increasing disappointment with the introspective methods of Titchener's (1989) psychology (among other reasons). Titchener was a student of Wundt but became resistant to his master's criticisms of introspection of which his fellow countrymen knew at that time and continued to know about close to nothing about it. They knew even less about inner perception that Wundt was scrupulous to discern from introspection considered as worthless if at all possible inner observation.

Watson vehemently rejected Titchener's introspective psychology and found himself among those who reduce psychology to biological investigations. Wundt, however, much the same as Brentano, did differentiate two areas of psychological science. Physiological psychology is one and belongs to the natural sciences (Naturwissenschaften). Psychology of the human mind is a part of the social and humanistic sciences (Geisteswissenschaften). Neither Brentano nor Wundt had played any significant part in further development of psychological investigations. Psychology has continued by studying behavior of organisms in their natural environment.

Psychological investigations over the next decades, until contemporary cognitive psychology can be called into question because of their legacy of behaviorism. They would probably not win in the field without Watson's inclusion of Pavlov into his psychology. Pavlov was the Nobel Prize laureate of 1904 and his experimental work provided for a breaking point in physiological research. Theory and research on the conditioning of responses to environmental stimuli became in Watson (1913) the foundational model of his theory of learning and any other learning theory that was proposed later up to present day cognitive theories. For example, Bandura's social cognitive learning theory (Bandura, 1975, 1986, 1997) assumes physiology of learning even when replacing Pavlov's terms with a language of new technology of brain studies without contradicting the essential move of the behaviorism classics of reducing psychology of mind and personality to the physiology of learning conceived as acquisition of behavior by experience of environmental stimuli. What is reduced are mental (psychic) functions serving the general function of adjustment (adaptation) to the environment. They undergo age-developmental changes in efficiency within the cycle of progression, plateau, and regression throughout the individual life course.

Behavioral knowledge of how behavioral habits are formed and how they expire fits the purpose of behavior modification in children, youth, adults, and older individuals by making use of human organism adaptability. It was not accidental that Pavlov took up typology of the central nervous system to argue for qualitative variants of brain activity patterns depending on the temperament of individual human beings. Higher neural activity, as he put it, varies from individual to individual depending on the temperament difference between them.

Making reference to the Hippocratic typology of temperaments, Pavlov gave his own interpretation of melancholic, choleric, phlegmatic, and sanguine personality types in terms of the differentiated patterns of brain processes features. The temperamental difference, and the differences in (psychometric) intelligence, and (questionnaires') personality differences affect the individual experience in the environment and bring about differences of individual behavioral repertoires. I put the qualifications of both psychometric intelligence and the questionnaires' personality to distance myself from use of the terms "intelligence" and "personality" in the literature regarding individual differences. Research in these fields suffer from absence of any theory of intelligence, as well as any theory of personality. It is also evidenced that there is no need to have a theory. Instead, there is a curious perpetuation of the conviction with no substantial reason that intelligence is what the intelligence scales measure and personality is what the personality questionnaires measure.

It is worth notice that the individual repertoire of habitual behaviors is formed in response to the habitus of the repeating events and processes in the environment. For this reason, the knowledge from the studies of behavior prove to be useful, either in behavior therapy or in upbringing and education, in addition to marketing, personnel development, administrative order, mass communications, and propaganda endeavors. In all of these 
fields, undesirable habits are eliminated with the means of punishment (not necessarily severe ones), and rewards (not necessarily the highest ones) serve to introduce desirable habits. For our purposes, the term 'habit' is defined as the all-encompassing class of repeatable procedures to be followed in due circumstances or any other principles, rules, or strategies imposed by social order institutions; in a word, any kind of behavioral reinforcement regimes acting upon an individual in the social environment to control their behavioral repertoires. Even creativity training popular a few decades ago had a clear aim to establish the habits of a creative approach to solve recurrent problems of different kinds. The same may be noticed in the area of creativity research, where so-called mechanisms of creativity are proposed to explain how the human mind works to produce creative solutions.

A similar approach can be found in the field of free will studies in connection to self-control, free choice, and - less frequently - in association with responsibility for decision taking. These investigations aim to discover laws or principles according to which free will operates by force of the subject's own unrestraint decision, i.e., as a consequence of free choice by the subject and taking responsibility for it by the subject. The apparent inner contradiction of the approach, such as rules of free choice, escapes the investigator's attention. The question that arises is why it seems not to be absurd to speak about the attempts to discern the rules of free will operation or to discover laws of free decision taking or to learn the causes of free choice or the effects of responsibility taking. It is evident that the rule of free will is that there no rules apply to it. There are no laws of making decisions of free will. The causes of free choice reduce to where there are no causes of it. The effect of responsibility taking has no effect at all, being an apparent effect without a cause.

It becomes clear in light of the above paradoxes that the meaning of the key terms in use by them changes when we move from a technical behavioral language, which is a language allowing reference to a determinism of cause and effect relations, (anger in this language means a specific pattern of the physical environmental and physiological organism processes as well as the organism glands secretions and movements of musculature), to the everyday language in which anger is experienced by a human subject with specific to this emotion reference to an object of anger. It is a promise of discovering the cause and effect laws that are given by behavioral and cognitive psychology. Nothing similar to that promise appears, not in common sense psychology, nor in the psychology of human mind and personality. Anger, as experienced by human beings, is not devoid of mental quality as any of the brain neural processes are, because when it becomes irrational anger, it still has a reference to the real world. Irrational angers are born out of a misperception of reality, which is a reference to an illusion of it. A reference to an illusory object is still a reference to an object and does not turn into a behavioral-physiological process.

Experience of anger in any person always has an underlying physiological process, but is not identical to it.
Human anger is a mental act which takes place according to its autonomic nature, which consists in reference with anger by the subject to an object. For example, anger borne from perception of unfair treatment of a pupil by a teacher may make his or her parent unable to control it. As a result, the parent is not a subject of this emotion anymore while the object of anger, i.e., the unfair treatment, is substituted by ascribed maltreatment of the child, in which the meaning of reference to a case of injustice becomes blurred. As a result, mental chaos follows, threatening the integrity of social relations in school and in the larger community as well. A human being who is possessed by anger to such a degree that they are going at their wit's end does not become an organism and the anger does not turn into a pattern of physiology events. Much the same as having control over one's own anger and making the rational choice of conduct in social relationships, a human being does not cease to live the life of one's organism. Psychophysiology processes in good standing are necessary in order to obtain the autonomous character of mental acts. However, they are not enough for it on their own. They must be completed by (1) a mental act of resistance against an emerging threat of social bond destruction when the subject would be taken by irrational outbursts of blind anger; and (2) if the resistance appears to be effective, then it makes it possible for the subject to deal with the injustice in an estimable manner to stop it, prevent it from happening, or to recuperate it rather than to expose the social bonds to danger. It is rather obvious that different interpretations of the opaque - and not immediately accessible by the human mind ideal of fairness and justice come into play by the parties involved. It is only natural that they differ from each other, but because being estimable human subjects they resist the irrational course of dealings and achieve the common realization of fairness and justice in the circumstances by a proper consensual resolution.

It is worth to note that independent of theoretical orientation, psychologists do not have any difficulty with the simple acceptance of human will operation, making choices, and taking responsibility for them. The difficulties arise for psychologists in scientific theory building when it occurs that access to the ideals of freedom and liberty can fit our mind with the real and powerful desires to act in accordance with our interpretations of justice and fairness. The same goes with many other vague and not immediately accessible ideals of social coexistence and collaboration. Both behavioral and cognitive psychologies are left incapable to deal with cognition of how the human mind operates, making individual people able to exercise free will and take responsibility while acting within the real social-cultural world.

The only apparent remedy continues to be applied due to years of inability to deal with the above mentioned incapability in psychological science. It stems from an invention of operational definitions of scientific terms inspired by the empiricist theory of scientific cognition (Bridgman, 1927). As a result of operational definitions, the terms referring to the inaccessible entities for immediate observation are defined in terms which enjoy such 
a reference. A classic example in psychology of such an operational redefinition of freedom and dignity appears in Skinner (1971) as a result of his ruthless criticism of the value discourse for the ideological bias and subjective involvement of participating parties which are unacceptable within an objective science of behavior. It is interesting that his severe criticism of the freedom and dignity discourse have not discouraged cognitive psychologists, who do not differ in basics of behaviorism, to reintroduce the once exiled phenomena into the scope of investigation.

The science of behaviorism offers a definition of the aim of psychology to be the description and explanation of behavior. The explanation may go on in terms of cognitive processes, as well as in terms of the various kinds of multidimensional individual differences or in both kinds of terms. It also offers hope for gaining knowledge of laws of human activity in the social-cultural environment, which is equally objective as the natural science knowledge is considered to be. There is also a promise to exercise control over human behavior in the fields of therapy, upbringing, education, training of interpersonal skill and sensitivity, different enterprises and other kinds of engagement in social behavior. It is not only clear that behaviorism and cognitive psychology reduce themselves at the end of the day to biology (life sciences), but they also offer the questionable service to social practice except for the fields of pathology and therapy.

Prevention and treatment of disorders, however, demand a therapist to train a patient to discipline and control their own behavior with the aid of following prescribed routines. To decide to do it, the therapist requires consent to his or her actions. This means that the patients voluntarily decide to subdue themselves to strict discipline in therapy. There is not much chance therapy will end in success without following the agreement. One may notice that it is the same in any other routine, procedure, or regulation which are obligatory and socially sanctioned in the environment of our everyday life. We inflict punishments as a result of free will decisions and when our free will is not strong enough to resist temptation, it is the fear of punishment which may make our will strong enough to stop our unacceptable actions. Rewards serve the same purpose by making our will stronger and less prone to unacceptable actions. Regulations of any human conduct with punishments and rewards would not be possible without human free will operating in our world.

It is not only obvious that there is no way to reduce human action to habits of human behavior, not to mention animal behavior, but also the reason why it is so is clear enough. The habits of human behavior originate in human action, not in animal learning. Human action is composed of beliefs and desires. Both imply the human subject referring to the objects. Beliefs are cognitive referential states and human desires are referential implying beliefs of what is worthy of acting for (Niemczyński, 1980c, 1980d; Macnamara, Govitrikar \& Doan, 1988). Cognition, free will, choice, decision, and responsibility play crucial roles in shaping human action within the human social-cultural world. Habits of human behavior are derivatives of human action, which introduces them to the repertoire of human behavior and withdraws them in ways unprecedented in other living creatures.

In the real world, it occurs that it is quite opposite to Skinner's reduction of mind to behavior. Autonomous human minds provide for human repertoires of habitual behavior. Skinner's criticism of the ideals of freedom and dignity appear to be a justified condemnation of the distortions of the ideals in the history of humankind by hidden hypocrisy, stupidity, and a desire for power. However, it does not justify giving up the ideals by pointing to their distorted realizations in some cases. The very disclosure of the ideal distortion and criticism of the perversion of it assumes the acceptance of reality of the ideal. In the case of social ideals of freedom, dignity, justice, solidarity, equality, etc., there are constant occasions for abuse, partly because they are vague and obscure ideals. The obscure ideals are not accessible to the human mind either directly or completely. They can be grasped only with the means of interpretation and realized partially. They are not perceptible by the senses and are abstract objects accessible to intuition (Brentano's and Wundt's inner perception). Contrary to the positivistic theory of cognition, they are not abstracted from the external perceptual observation. Ideal objects are referred to with mental operation by the human mind, and our intuitive knowledge of them can be communicated and corrected by any subject participating in the social discursive processes (Macnmara, 1990; Niemczyński, 2000).

Besides ideals, the other ideal objects are kinds. They can be found in Aristotle's logic of categories in contrast to the contemporary logic of sets. Kinds has been discovered by Macnamara in his psychological research of the logical aspects of the human mind. They are the abstract objects of human cognition and guarantee our knowledge to be commensurable, compatible, and in correspondence with the objects we refer to within the real world. The beliefs such as: "This pet is Macnamara's dog named Freddy," "This murmur of these lungs signals a morbid change" or "This streak in a gas chamber marks an elementary particle movement," all refer to a world where objects like dogs, lung diseases, and elementary particles, among many other kinds of objects of which we can obtain knowledge, exist. It means that our mind has a way to provide recognition of individual instances of the same category DOG or LUNG DISEASE SYMPTOM or ELEMENTARY PARTICLE MOVEMENT. Each category spreads across not only all the present individual instances, but also embraces all the past individual instances, as well as all the future individual instances. Individual instances of each category are situated in definite time and space. In contrast, the categories (kinds) are ideal objects and have neither spatial nor temporal coordinates.

The human mind accesses kinds with intuition (inner perception in Wundt and in Brentano). We can be aware of a reference to a category (ideal object) incidentally (nebenbei in German) in the course of perceiving an object to be recognized as the individual case of the category. Usually, we do not use intuition to this end. Besides 
the special occasions of psychological experiment, we stay without any awareness of operation of the mental device of reference to a kind providing identification and individuation of the object. The device seems to operate like a goal directed servomechanism. It begins upon incidence of particular circumstances. Once I have a view of Freddie, it puts into operation the mechanism of assorting a kind DOG, but not CAT, which belongs to Macnamara but not to anyone else, and whose proper name is Freddy but not Teddy like the other dog in the house is named.

There is no escaping the question about the origins of furnishing the mind with arrangements of recognizing objects to be the individual instances of various kinds. In other words, it is the question of how the human mind accesses the arrangement of the ideal objects. The question of particular significance for us here refers to the role the processes of individual development play in such arrangements of mind and personality within the life cycle of homo sapiens species representatives. Asking the last question, we are immediately seized by the unending nature vs. nurture controversy over what is innate and what is acquired. There are several layers of this debate and a necessity to clarify them first and the mutual relationships between them exists. I am not going to explain how to treat the muddled issues of biology, psychology, education, sociology, axiology, epistemology, ontology, and metaphysics. Perhaps it will suffice for now to change tactics and take a different route by asking the question in a slightly different way. Instead of a dispute over what comes from where in the human mind and personality development in children, we may attempt to establish the uncontroversial achievements of their development; for instance, in the area of locomotion, speech, or within any other area.

Let us use dancing in the area of locomotion development in preschool children. We will see how the first simple steps are taken in making movements in the set pace and rhythm of a simple melody under guidance of a teacher and how they grasp the pace and rhythm to produce the movements accordingly. In the field of linguistic development, let us consider the production of the first complete sentence.

A task performed by a teacher is to invite children to learn how to move in the pondered case with a set pace and rhythm and to introduce them into the circle of a certain form of the ideal of beauty. Both teacher and pupils invoke their intuitive interpretations of this ideal, which belongs to the opaque and indirect ones. It can be seen easily in clear orientation at the achievement of a more perfect fit of body movements to the melody pace and rhythm. The dance transmitted to children in music education is taken by the teacher from the cultural resources of the community and used with the proper interpretation of the ideal of beauty. We can take a closer look from the beauty ideal perspective at the typical pattern of the dance involved and make observations or experiments to establish what is learned by the child in the course of upbringing (education, learning, instruction) and what the previous (prior) competences of the child are, which are necessary to make the observed learning achievements happen. It is possible to establish what can be accepted to be innate by the present state of our experimental knowledge in this field and what comes from interactions with adults and other children. All the parties involved in the social interactions are able to profit from access to the ideals in their own interpretations and get in touch with the interpretations of the other participants, as well as with the standard interpretations accessible from the cultural resources of the community.

There is little research data available on children's dance (musical, artistic) development and the innate preconditions of it. The situation is different in the area of children's linguistic development. Here we have a vast store of data, experimental procedures, exploratory inventions, and well-founded claims. A classic example we may refer to is the critique by Chomsky (1959) of Skinner (1957) for his explanation of how children learn their mother's tongue. Chomsky was not interested in the nature and nurture controversy, though he unequivocally considered the universal linguistic competence to be an innate species-specific feature of homo sapiens. He did not diminish the necessary role of linguistic community in acquisition of a mother's tongue by children. His focus was on syntax and he applied his linguistic intuition to study the syntactic structures. What he found was that he was able to communicate and make corrections available by the intuitions of others. Chomsky referred directly to a notion of the ideal user of language and looking at the concrete utterances from this perspective, he was able to discover the underlying pattern (Chomsky, 1957, 1964, 1965). Macnamara used a similar style in his studies of the logical aspects of the human mind (Macnamara, 1982, 1986; Macnamara and Reyes, 1994) and in his studies on child learning of the semantic aspect of language. Ample series of experimental works on linguistic development of children and youth in Hall's $(1994,1999)$ laboratory continues to use and extend the same kind of conceptual model of language learning (Hall et al., 2004, 2010). They firmly suggest that the ability of reference to ideal objects is a competence of the human mind, which plays a crucial role in children's learning process within the human socialcultural world. This process is not the learning process as conceived by cognitive psychology or behavioral psychology (see Hall and Bellager, 2005) in accordance with the philosophical doctrine of empiricism. To go further beyond the limits of the empiricism doctrine, one needs to return to the relationship between the biological and mental after rejection of their identity to each other.

\section{Spontanous self-sustained perception vs. self-determined mind}

Gibson (1966, 1986; Niemczyński, 1972a, 1971b) introduced the innovative notion of optical arrays to emphasize the structural nature of the stimulus for visual perception. His theory also proved to be an innovative move in treating the senses as the active 
perceptual systems. He argued that it is the object against background in the environmental space that is the source of light structure in the optical arrays of stimulus for visual perception. The invariant of optical structure which is discerned as a consequence of the optical arrays exploration is the effective stimulus within the visual system.

Not without influence of physical empiricism in the theory of perception, Gibson postulates a gradual attuning of the perceptual system to the invariant of stimulus structure in the course of exploration up to the final attunement in achieving the state of resonance by the system with the invariant of the stimulus structure, which is the effective stimulus for the perception of the environmental source of the structure. Let us put aside the physical metaphors and notice that as a result of exploring, for example, the room in our house to the right of the entrance to a figure (German Gestalt) of the antique armchair emerges in the background of the corner of the room which continues to the adjacent and further parts of the whole living room as furnished with many other things. We may easily make a shift of attention between the armchair and the corner of the living room to see alternatively the corner behind the armchair or the armchair in the corner. Both perceptual finals may be achieved at will, depending on how we voluntarily direct our attention. It is up to our free will to determine which real object we choose to perceive on which real background.

Gibson profits from Gestaltpsychologie and uses it to his own ends in describing the structural and dynamic nature of stimulation for the senses considered as active perceptual systems. It is worth notice from our perspective that what is perceived is the object situated in space and in time of happening in the environment and as such, a real object can be explored and perceived, given that the ambient lighting reverberates in the environment and provides the real possibility of exploration for the perceiving subject.

It is not difficult to notice that it is a metaphysical statement basic for the theory of perception and cognition and necessary to state that the objects of perception are real and are situated in real space and in real time where they are illuminated by ambient light, making it possible that the content and furniture of the real world are perceived. These are evidently the ontological declarations about the existence and structure of the world within which the sensual perception takes place. Ontology of this world refers not only to the physical nature of it, but it also clearly refers to the state of objects in space, time, and to the illumination of them which makes them visible to the subjects of perceptual acts. This continues on a theory of material basis of the visual perception objects. This theory is about the illumination with the light clusters reverberating in space among the furniture and revealing features of objects within the real world. The crucial element for this theory of material basis of visual perception is the attunement process of the active exploratory system of vision (moving eyes on moving head of moving body) to the structural invariant corresponding to the discerned visual figure to be perceived on the environ background. One can hardly find more firm doubt of metaphysical assumptions of empiricism in theory of perception and knowledge. There are no atoms of sense experience, no elemental physical impacts on the senses, no pieces of empirical data to be the raw material of elements to construct of them the knowledge of the external world by making synthetic theories. Instead of the physical atomic structure of the environment from Gibson, it is an ecological description of the world of living organisms. They are immersed in the their environs and are sensitive to a variety of different kinds of affordances to be informed about what actions are allowed to be performed where, at what time, and in what spaces. Gibson coined the term of affordances for activity opportunities, which are offered by the environment to be detected by active perceptual systems of living organisms in species specific ecological niches.

One should add to the description of the world of veridical perception in terms of behavioral ecology and its integral part of being the activity of senses organized into systematic search for the environmental affordances to be detected and used in efficient actions within the econiche. It includes the movements of the sense organs, for example, movements of the eyes on the moving head of the moving human being, to obtain flows of environmental stimulation of the receptor organs innervations to be transferred as transformed into the nerve impulses to the afferent neural routes leading to the central nervous system centers of elaboration of the sensory input and transform it to an outgoing pattern of impulses down the efferent neural routes to the peripheral innervations of the muscles and glands to make them act accordingly. The above descriptions stay within the real world as discovered by a physicists' type of investigation. It is time to make it alive by adding sensitivities and perceptions, mind and intuitions, culture and religion, knowledge, and morality. To begin, let us focus on the senses and perception, on the one hand, and on mind and intuition, on the other hand.

I take the opposite direction to the empiricism theory. Empiricism is considered here to be the theory of cognition which is open to reduction of perception and mind to the physical and physiological processes. My opposition against this theory of cognition (Niemczyński, 2016b) introduces the impassable barriers for such reductions of spontaneity and self-sustainability of the active senses and perception and introduces affirmation of the selfdetermination of mind and cognition. As a result of putting aside empiricism, a perspective is revealed on perception and cognition to treat them as two different kinds of acts of the human subject. Both are spontaneous acts and cognitive is the self-determined act of the human mind. Empiricism puts the equation mark between perception and cognition. Such a confinement of cognition in perception began with Hobbes (1651/1961). It is also the essence of the first reduction of psychology to kinematics of Galileo by Hobbes in XVII century. Since that time, psychologists have not ceased conducting psychology by reducing it to something else. In XXI century it is still biology together with population research statistics which enjoys unfading popularity since about fifteen decades. In the last few 
decades, psychologists marvel information technology devices.

Spontaneity and self-sustainability of perception does not mean its independence from physical and physiological processes. Instead, it means that perceiving is the subject's own operation in which one may discern (1) a turn of exploration and focus of attention on an explored object in the environ, (2) bringing the object to the fore against the background, and (3) identifying the object to be a concrete individual of a certain kind of objects. Such a spontaneous and self-sustaining takes place on the foundation of the indicated processes of physical and physiological nature. However, it is accomplished in a different process, in which it does not lose contact with the foundation, but proceeds according to different kinds of principles than those governing the foundation. It is like walking over the ground of Chochołowska Valley in the Tatra Mountains. There is no walking without the ground to walk over, but walking occurs with its own rules to follow, and they are different than the laws applicable to the grounds affording the walks over them. As a matter of fact, there are mutual influences between perception and its physiological foundation despite spontaneity and selfsustainability of perception, which is not endangered by the influence of the organism's physiology. Perceptions by the subject of the objects within the environ world reflect on physiological processes within the organism as much as the very activity of perceiving the objects in the world by a human subject is influenced in a number of ways by physical environmental processes and by physiological processes of the human organism. However, neither of these two are parts or parcels of the perceptual activity. The last one consists as mentioned in three stages of focusing attention and exploration on the object first, then making a clear enough differentiation between the object and the background for the object to be noticed on the background, and finally recognizing the perceived object as to its identity, (what kind of object it is), and individuality, (which individual of the indicated kind is this concrete one). Each time the perceptual act by the subject perceiving the object perceived takes place, one may observe its three stage constitution, in human beings, in animals, or even partially in apparatuses serving as an aid to our perception of events not easily accessible or not accessible at all to immediate exploration by us with our senses.

While staying within the limits of perception, the subject enjoys a limited degree of freedom. Free will operates only in the choice of object for perception and the choice of desire which is aroused to be appropriate to be realized while in the perceptual contact with the object. The complete performance of the perceptual act to its end encompasses several turning points in which it is decided what is going to be the attentive focus of perception, what is going to be the figure on the background, and what is going to be the categorical identity, e.g., DOG with individuation of the object, e.g., this concrete one here. Spontaneous and self-sustainable nature of perceptual acts implies the circular reactions of Baldwin (1896) which were observed in the manipulation and exploration of objects by children. Piaget (1936) used the term later with reference to observations of his own children since day one of postnatal life and depicted a progression from the primary circular reaction to secondary through the third order circular reaction. Neither Baldwin nor Piaget, however, speak of spontaneity and self-sustainability of perception in children. Admittedly, Baldwin noticed spontaneity and Piaget saw the beginnings of autonomy in relation to the environment. It is understandable because they have not gone beyond the empiricism theory of cognition, despite the fact that Piaget abandoned the mental elements and associations on behalf of the mental structures. Both of them, however, treated perception and cognition as if they were of one piece and could be seized and grasped within one theory. Each of these authors use slightly different primary concepts, but both investigators build their own theory of cognition (intelligence), running perception and cognition together. For example, autonomy in Piaget is ascribed to both the sensory-motor adaptations of the baby (even newborns) and to the mental acts of adaptation in adults. Meanwhile, I argue that the acts of perception of environmental objects are not autonomous. They are rather spontaneous and self-sustained. Cognition is spontaneous and autonomous, although not exactly in the way it was presented by Baldwin or by Piaget. Before going further, it is worthy of note that realism in theory of cognition implies the basic triadic structure of the cognitive act, i.e., the subject of the cognitive act, the object of the cognitive act, and the relationship of reference by the subject to the object of the cognitive act. Everything in the cognitive act is spontaneous and autonomous. As was shown earlier, the basis of ontological illusion of empiricism is the notion of experience without both subject and object of it, but exercising power of production of the cognitive representations of the object and the subject of the sensual perception and cognition all the same.

Autonomy of mind considered as mind selfdetermination implies emancipation of mental acts from determination by any contingencies of time and space. Within the concrete circumstance, Archimedes got illuminated and discovered the law of apparent loss of weight by the solid body while it is immersed in a liquid. However, the law does not apply only to this particular incident and the discovery must neither happen that day nor in that place nor even while in the bath. The discovery must not happen specifically to Archimedes. Also, other than the bath, data of senses could give an opportunity to discover this lawful course of events by many other deliberating and experimenting human subjects. Not to mention that neither actual observation nor experiment are necessary to suggest the relationship in imagination or in fantasy. To the contrary, it may be noticed that the subject activity in sensual perception is not independent of external determination, despite that it is spontaneous and self-sustainable. The perceiving subject can focus attention on the object perceived and explore the object to discern it against the background and finally recognize the object to be an individual of a kind. Perception is dependent on 
the object perceived. It is the object which attracts and catches the attention of the subject, who is aroused by the object and gains curiosity to find out of what kind the concrete individual is which is perceived. It is exactly this culmination of the perceiving act in assorting the object to a kind as an individuated member of it that may suggest that there exists a common denominator of perception and cognition. It is the conviction of empiricism that they go together in one piece and demand one theory of cognition. I will soon return to this question.

Ajdukiewicz (1934) unfolds the postulate of antiirrationalism in opposition to the reduction of the triadic relation terms of subject, object, and cognitive operation of the subject with reference to the object. As a consequence, he postulates the inter-subjective - both access to and correction of - the proposition's interpretation. In the end, it matters only whether what is said about the object in the proposition referred to it is true or false.

It is the capacity of the human mind that can defend us against invasions of irrational convictions and liberate us from them where they already reign. It implies that human mind autonomy is in permanent conflict with the forces of the natural adversary, i.e., with the heteronomy position of the mind. Cognitive acts of the human autonomous mind are empowered by the desire for truth, which has to struggle with craving for the other values. The last ones can blur and obscure what is said in the propositions or even substitute falsity for truth of the proposition. It is not easy to find a better illustration of these dramatic and emotionally loaded struggles than the psychoanalytic defenses of ego by use of the falsities to prevent it from confrontations with the unpleasant truths. In the other fields, one may take the power of advertising and marketing inventions or the propaganda forces to see how potent the invasions of falsity are in the name of economic profits and political benefits at the expense of truth. There is no surprise that even in science, the potent competition drives scientists into pursuit for other values than the truth of the propositions. It occurs that the cognitive value, i.e., truth or falsity of a proposition, is not dependent on being recognized. This is exactly the reason why it is so important to be able to identify the cognitive value. The non-classical theories of truth make quite a lot of proposals for how it can be done. There are among them: (1) illumination of the mind or intuition, (2) coherence of propositions, (3) general consensus over them, (4) usefulness, (5) effectiveness in action, (6) leading to efficient, competent action, (7) bringing success in action, and (8) applicability in practice. One can see that each of the invoked criteria may be of use in testing the cognitive value of propositions and it can be said that in light of them, the varying degrees of certainty can be reached in recognition of the truth or falsity of propositions. The anti-irrational attitude does not imply absolute certainty of the outcomes of testing for reaching a conclusion of acceptance or rejection of the proposition. Instead, it does imply the confidence in conclusion be proportional to the achieved degree of certainty of the cognitive value recognition as a result of testing the proposition.
The problem of cognition as outlined briefly above allows us to clearly see that the autonomy of the human mind arises out of yearning for truth on the ground of the human subject reference with propositions to the objects in the real world. The desire for truth can be satisfied from the perspective of anti-irrationalism to a degree which is proportional to the degree of certainty allowed by the outcomes of the social, inter-individual process of testing the proposition for its cognitive value. Truth or falsity of a proposition is a feature of the relation of what is said in the proposition about the object to how the object really is. If it is said that the object in the proposition really exists, and it is shown that the object really exists and really is as it is said to be, then what was said in the proposition is a truth. If it is said that the object in the proposition really exists, and it is shown that the object does not really exist, then what was said in the proposition is a falsity. If it is said that the object in the proposition really exists, and the object really does exist, but the object is not really what was said in the proposition, then the proposition is a falsity.

If the above formulations can define truth and falsity in accordance with the Aristotelian classic notion of cognitive values, then a question is to be asked about the criteria of truth and falsity. This question is in regards of how to decide whether the object referred to in the proposition really exists or does not really exist. If it really exists, then the question is how to decide that it really is what it is or that it really is not what it is. All of the previously mentioned non-classical conceptions of truth are, in fact, such a criteria. I am not going further into the theory of truth here. What was said about it must suffice for now to bring the reader's attention to the fundamental status of autonomy of human mind and cognition. The status consists of the power of the production of truths and falsities about the world by constructing propositions about what exists in this world and how it is furnished and equipped. This is also the power to resist the falsity claims in order to emancipate the truth. It operates on the ways of unrestrained access to the propositions and to all of the existing grounds for what they mean and how they are of value. Free access for all who are ready to consider the grounds of claims openly, with resistance to be foreclosed, and who strive after a weighted and balanced position which would define and eventually resolve the competing claims for what is of cognitive value. Each and every participant of this social process of inter-subjective communication about our world we live in spare no effort to take, and remain in, the position of antiirrationalism while supporting others in taking and staying in it without any success guaranteed, but with readiness to assume the strivings anew.

A word is still due regarding mutual differentiation between the spontaneous and self-sustained sense perception on one hand, and the autonomous and selfdetermined mind, on the other hand. This paper was interested not in the cognitive value of perceptions, but propositions, and it is this value of truth and falsity which is at stake in struggles against the threats to mind integrity by irrational forces. Sense perceptions are neither truths 
nor falsities, because they are not propositions. They may be and may not be veridical and reliable, but to recognize how they are one would need to go beyond perception to the realms of mind, cognition, and action.

One more word about the question of human personality toward which all of what was said leads, though does not reach it. Theory and data on personality development from adolescence onward has been presented earlier (Niemczynski, 2007). Personality and its development in childhood must be left for future occasions.

\section{References}

Ajdukiewicz, K. (1934). Logiczny antyirracjonalizm w Polsce. Przegląd Filozoficzny, 38/4, 399-408.

Allport, G.W. (1927). Concept of trait and personality. Psychological Bulletin, 24, 284-293.

Allport, G.W. (1937). The functional autonomy of motives. American Journal of Psychology, 50, 141-158.

Allport, G.W. and Odbert, H.S. (1936). Trait-Names. A Psycho-lexical Study Psychological Monographs, Vol. XLVII, Whole no. 211

Bandura, A. (1975). Social Learning and Personality Development. New Jersey: Holt, Reinhart and Wilson Inc.

Bandura, A. (1986). Social Foundations of Thought and Action: A Social Cognitive Theory. Englewood Cliffs, New Jersey: Prentice Hall.

Bandura, A. (1997). Self-efficacy: the exercise of control. New York: W.H. Freeman.

Berkeley, G. (1709-13/1965). Berkeley's Philosophical Writings. Edited by D.M. Armstrong. New York: Collier-Macmillan.

Blum, L.A. (1994). Moral perception and particularity. Cambridge: Cambridge University Press.

Brentano, F. (1874/1973). Psychologie vom Empirischen Standpunkte. Leipzig: Verlag von Duncker \& Humbold. Translated into English as Psychology from an Empirical Standpoint by A.C. Rancurello, D.B. Terrell, and L.L. McAlister. London: Routledge and Kegan Paul., 1973.

Bridgman, P.A. (1927). The logic of modern physics. New York: Macmillan Company.

Chomsky, N. (1959). A Review of B.F. Skinner's Verbal Behavior. Language, 35, 1, 26-58.

Chomsky, N. (1964). Current Issues in Linguistic Theory. The Hague: Mouton and Co.

Chomsky, N. (1965). Aspects of theory of Syntax. Cambridge, MA: MIT Press.

Czyżowska, D. and Niemczyński, A. Universality of social-moral development; a cross-sectional study in Poland. Journal of Moral Education, 4, 25, 441-453.

Fowler, J.W. (1981). Stages of Faith: The Psychology of Human Development and the Quest for Meaning. New York, N.Y.: HarperCollins Publishers.

Gibson, J.J. (1966). The senses considered as perceptual systems. Boston: houghton-Mifflin.

Gibson, J.J. (1986). The ecological approach to visual perception. Hillsdale NJ: Lawrence Erlbaum Associates.

Golec, A. and Niemczyński, A. (1995). Relativistic Climate for Personality Development. Polish Quarterly of Developmental Psychology, 1, 1 , $18-18$.

Hall, D.G. (1994). How Children Learn Common Nouns and Proper Names. In J. Macnamara and G.E. Reyes (eds) The logical foundations of cognition. New York, Oxford: Oxford University Press.

Hall, D.G. (1999). Semantics and the acquisition of the proper names. In R. Jackendoff, P. Bloom and K. Wynn (Eds), Languge, Logic, and Concepts. Cambridge MA: MIT Press.

Hall, D.G. and Waxmann, S.R. (2004). Weaving a Lexicon. Cambridge, MA: MIT Press.

Hall, D.G. and Belanger, J. (2005). Young children's use range or reference information in word learning. Developmental Science, 8, 8-15.

Hall, D.G., Williams, S., and Belanger, J. (2010). Learning count nouns and adjectives; Understanding the contributions of lexical form class and social-pragmatic cues. Journal of Cognition and Development, 11, 86-120.

Hempoliński, M. (2005). Prawda i racjonalność jako konstytutywne wartości wiedzy. In A. Motycka (red.) Wiedza a prawda. Warszawa: Instytut Filozofii i Socjologii PAN.

Hobbes, T. (1651/1962). Leviathan. Edited by M. Oakeshott, New York: Collier.

Hume, D. (1748/1962). Enquiries concerning Human Understanding. Edited by L.A. Selby-Bigge. Oxford: Clarendon Press.

Husserl, E. (1900). Logische Untersuchungen; Erster Teil, Prolegomena zur reiner Logik. Halle: Max Niemeyer.

Husserl, E. (1901). Logische Untersuchungen: Zweiter Teil, Untersuchungen zur Phanomenologie und Theorie der Erkenntnis. Halle: Max Niemayer.

Ingarden, R. (1964). Der Streit um die Existenx der Welt. Bd. I, BII/1, BII.2. Tubingen: Niemeyer.

Ingarden, R. (1974). Uber die kausale Struktur der realen Welt. Der Streit um die Existenx der Welt. Band III. Tubingen: Niemeyer.

Ingarden, R. (1970). Uber die Verantwortung. Ihre ontische Fundamente. Sttutgard: Reclam.

Koclega, R., Niemczyński, A., Ryniak, R. and Ziółkowska, A. (1995). Differences in Moral and Personality Development Connected with Gender. Polish Quarterly of Developmental Psychology, 1, 3, $143-149$.

Kohlberg, L. (1981). Essays in Moral Development: The Philosophy of Moral Development. New York: Harper and Row.

Kohlberg, L. (1984). Essays in Moral Development. The Psychology of Moral Development. New York: Harper and Row.

Lerner, R. (1986). Concepts and Theories of Human Development. New Jersey: Lawrence Erlbaum Associates, Inc.

Locke, J. (1690/1894). An Essay on Human Understanding. Edited by A.C. Fraser. New York: Dover.

Macnamara, J. (1982). Names for Things. A Study of Human Learning. Cambridge, MA: Bradford/MIT Press.

Macnamara, J. (1986). Border Dispute: The Place of logic in Psychology. Cambridge, MA: Bradford/MIT Press.

Macnamara, J. (1990). Ideals and Psychology. Canadian Psychology, 31, $14-25$

Macnamara, J. (1999). Through the Rearview Mirror. Historical Reflections on Psychology. Cambridge, MA: MIT Bradford Books.

Macnamara, J., Govitrikar, V.P., and Doan, B. (1988). Actions, laws, and scientific psychology. Cognition, 29, 1-27.

Macnamara, J. and Reyes, G. (eds.) (1994). The logical foundations of cognition. New York, Oxford: Oxford University Press.

Mill, J.S. (1843). System of logic. London: Longman's.

Niemczyński, A. (1972a). Recenzja ksiązki J.J. Gibsona „Senses Considered as Perceptual Systems". Psychologia Wychowawcza, 3, 361-365.

Niemczyński, A. (1972b). Recenzja ksiązki E.J. Gibson „Principles of Perceptual Learning and Development". Psychologia Wychowawcza, 3, 365-373.

Niemczyński, A. (1977). Zwiazki miedzy poznawczymi i motywacyjnym składnikami procesów regulacyjnych $w$ ontogenezie. Rozprawa doktorska na Wydziale Filozoficzno-Historycznym Uniwersytetu Jagiellońskiego: Kraków: Biblioteka Jagiellońska.

Niemczyński, A. (1980a). Modele indywidualnego rozwoju człowieka Kraków: Wydawnictwo Uniwersytetu Jagiellońskiego.

Niemczyński, A. (1980b). An Attempt of Critique of Epistemological Representationism. Jagiellonian University Reports on Philosophy, Vol. 4, 101-107

Niemczyński, A. (1980c). Biologiczne warunki i społeczna geneza twórczego działania. Zeszyty Naukowe Uniwersytetu Jagiellońskiego. Prace Psychologiczno-Pedagogiczne, vol. 31, 13-31.

Niemczyński, A. (1980d). Prymat treści działania nad sposobem jego regulacji. Zeszyty Naukowe Uniwersytetu Jagiellońskiego. Prace Psychologiczno-Pedagogiczne, vol. 30, 7-21.

Niemczyński, A. (1988a). Procesy rozwojowe w pełnym cyklu życia indywidualnego. In M. Tyszkowa (red.), Rozwój psychiczny człowieka w ciagu życia. Warszawa: PWN.

Niemczyński, A. (1988b). Afirmacja życia w ujęciu Antoniego Kepińskiego. Przegląd Lekarski, 3.

Niemczyński, A., Czyżowska, D., Pourkos, M., and Mirski, A. (1988c) The Cracow Study with Kohlberg's Moral Judgment Interview; 
Data Pertaining Cross-sectional Validity. Polish Psychological Bulletin, 1, 19, 43-53.

Niemczyński, A. (1992). Origins of human autonomy. A Dialectics of Adolescence Growing into Adulthood. Polish Psychological Bulletin, 23, 75-82.

Niemczyński, A. (1994). Empiryzm a zaangażowanie aksjologiczne psychologii. Zeszyty Naukowe Uniwersytetu Jagiellońskiego. Prace Psychologiczne, vol. 6, 127-131.

Niemczyński, A. (1994). O autonomii rozwoju. Zarys problematyki. Kwartalnik Polskiej Psychologii Rozwojowej, 2, 1, 3-11.

Niemczyński, A. (1996). Moral education is not moral enough because education is not moral enough. Journal of Moral Education, 1, 25, 111-117.

Niemczyński, A. (2000). Szansa na powrót ideałów do rozwoju poznawczego. Psychologia Rozwojowa, 5, 1-2, 11-25.

Niemczyński, A. (2007). Inner regulatory device for adult development. Polish Psychological Bulletin, 38, 3, 133-139.

Niemczyński, A. (2014). Dylematy wartości na różnych polach przedsiębiorczości. In Z. Ratajczak (ed.), Przedsiębiorczość czyli pochwała kryzysu. Katowice: Górnośląska Wyższa Szkoła Handlowa.

Niemczyński, A. (2015). Znaczenie teorii rozwoju dla empirycznych studiów psychologicznych nad indywidualnym rozwojem człowieka. Maszynopis przed drukiem.

Niemczyński, A. (2016). Odpowiedź na głosy z panelu o ratowaniu teorii indywidualnego rozwoju człowieka z zalewu danych empirycznych. Maszynopis przed drukiem.

Niemczyński, A., Maciejowska, A. (1989). Contextual relativism of moral judgment. In N. Eisenberg, J. Reykowski, E. Staub, Social and In- dividual Values: Societal and Individual Perspectives. Hillsdale: Erlbaum.

Piaget, J. (1932). Le jugement moral chez enfant. Paris: Alcan.

Piaget, J. (1936). La naissance de l'intelligence chez l'enfant. Editeur: Delachaux et Niestle.

Przetacznikowa, M. (1973). Podstawy rozwoju psychicznego dzieci i młodzieży. Warszawa: Państwowe Zakłady Wydawnictw Szkolnych.

Skinner, B.F. (1938). The behavior of organisms. An Experimental Analysis: New York: D. Appleton-Century Co.

Skinner, B.F. (1957). Verbal Behavior. New York: Appleton-CenturyCrofts.

Skinner, B.F. (1971). Beyond Freedom and Dignity. New York: Alfred A. Knopf.

Szuman, S. (1959). O czynnikach kształtujących psychikę dziecka w wieku przedszkolnym. Kwartalnik Pedagogiczny, 4, 143-158.

Tischner, J. (1982). Myślenie według wartości. Kraków: Wydawnictwo ,Znak”.

Ttchener, E.B. (1898). The Postulates of a Structural Psychology. Philosophical Review, 7, 449-465.

Watson, J. (1913). Psychology as the behaviorist views it. Psychological Review, 20, 158-177.

Wundt, W. (1897). Grundriss der Psychologie. Leipzig: Verlag von Wilhelm Engelmann.

Wundt, W. (1900-1920). Voelkerpsychologie, 10 Baende. Leipzig: Engelmann.

Wygotski, L.S. (1971). Wybrane prace psychologiczne. Przekład: Edda i Józef Flesznerowie. Warszawa: Państwowe Wydawnictwo Naukowe. 